University of South Florida

DIGITAL COMMONS @ UNIVERSITY OF SOUTH FLORIDA
Digital Commons @ University of

South Florida

\title{
Stellosphæra mirabilis, a New Asteroid Larva very Probably Belonging to an Abyssal Form. A translation of Stellosphæra mirabilis, nouvelle larve d'Astérie appartenant trés vraisemblement à une forme abyssale
}

\author{
René Koehler \\ Clément Vaney \\ John Lawrence \\ University of South Florida, lawr@usf.edu
}

Follow this and additional works at: https://digitalcommons.usf.edu/bin_books

\section{Recommended Citation}

Koehler, R. \& C. Vaney (2020). Stellosphæra mirabilis, a New Asteroid Larva very Probably Belonging to an Abyssal Form. A translation of Stellosphæra mirabilis, nouvelle larve d'Astérie appartenant trés vraisemblement à une forme abyssale. Comptes rendus hebdomadaires des séances de l'Académie des sciences, 142, 520-522 (J. M. Lawrence, Trans.). Herizos Press, Tampa.

This Book is brought to you for free and open access by the Integrative Biology at Digital Commons @ University of South Florida. It has been accepted for inclusion in Integrative Biology Books by an authorized administrator of Digital Commons @ University of South Florida. For more information, please contact digitalcommons@usf.edu. 
René Kœhler and Clément Vaney. 1906. Stellosphora mirabilis, a new asteroid larva very probably belonging to an abyssal form. A translation of "Stellosphora mirabilis, nouvelle larve d'Astérie appartenant trés vraisemblement à une forme abyssale." Comptes rendus hebdomadaires des séances de l'Académie des sciences. 142, 520-522. Translated by John M. Lawrence.

(C) 2020. John M. Lawrence, Herizos Press, Tampa, Florida. 
ZOOLOGY.- Stellosphæra mirabilis, a new asteroid larva very probably belonging to an abyssal form. Note of MM. R Kohler and C. Vaney, presented by M. Alfred Giard.

The larva that we describe in this Note was collected by S.A.S. the Prince of Monaco by pelagic fishing in the area of the Azores from 2,000 to 3,000 m depth by means of a vertical net with a large opening of Dr. Richard. It resembles no known larva of echinoderms and, moreover, in considering only its spheroidal form and its exterior characters, we would at first be tempted to refer it to a completely different group than echinoderms. Very happily, the presence of pedicellariae fixes immediately the systematic position of this curious organism. As these pedicellariae, which are crossed, are identical to those that we observe in forcipulate asteroids and that are found only in this group, we are justified in saying that Stellosphora is an asteroid larva.

The body is nearly spherical, but one of the poles, in the middle of which opens the mouth, is slightly flat. The diameter is approximately $3 \mathrm{~mm}$. At the stage of the youngest that we have been able to examine, the most curious exterior character of this larva is the presence of numerous calcareous bodies in the form of groups of spines at certain points on the surface of the body. We see at first six principal groups of these spines placed at equal distances from each other on the equator of the body. It thus gives the appearance of hexaradiate symmetry. Each group is composed of six to eight spines more or less inclined and inserted on a reticulated calcareous plate. These plates also have some crossed pedicellariae. Independently of these six equatorial bundles, we seen others, less important, toward the aboral pole. One of these, a single spine supported on a small calcareous plate, occupies exactly the top of the larva. Around this kind of centro-dorsal plate, are five other plates in a small circle. These are smaller than the equatorial plates and each has one or two spines and a pediciellaria. The mouth is flat. It has a sunken tentacle towards each end.

The only internal organ that we can distinguish is the digestive tube. It makes two spiral turns. The esophageal region has two lateral diverticula. The anus is slightly moved from the centro-dorsal plate. At a more advanced stage of development, the calcareous plates and their spines are resorbed. In place of the equatorial plates, we see an equal number of rectangular pads, each with five to seven tubercles often arranged in pairs between which are the remains of asperities formed by the spines. In sections, we still find some calcareous fragments but these are resorbed in large part. At the base of each pad, two pairs of more or less flat digitations have appeared. The plates of the aboral pole have also disappeared. We distinguish in this region only a centro-dorsal papilla surrounded by five other small papillae. As for the pedicellariae, they do not undergo any modification because they are found in older larvae with the same characters and the same arrangement as in the younger larvae,

There can be no doubt about the nature of Stellosphara: it is an asteroid larva, proven by the presence of forcipulate pedicellariae. We have no need to insist on the differences that separate it from the other larvae of echinoderm. These differences are striking and so marked that if the pedicellariae could not fix in an indisputable manner the position of this larva, we would relate it to the echinoderms with difficulty. The differences are so great that it is not necessary to make comparisons. We note however a remarkable character of Stellosphora: it is the hexaradiate symmetry that is shown by the six groups of equatorial plates and that persists, after the disappearance of the plates and the spines, in the six pads that replace them. The pentaradial symmetry is shown only by the arrangement of the secondary plates of the aboral pole. Finally, other characters, such as the presence of two buccal tentacles and the flat form of the mouth, show a clearly bilateral orientation. We thus find at the same time, in the same organism, hexaradiate, pentaradiate and bilateral symmetries.

We cannot confirm in an absolute manner that our larva belongs to an abyssal form because the fisheries that provided them were made between 2000 or $3000 \mathrm{~m}$ and the surface. There is a very high probability that the larvae were captured at a great depth. But one can object that, the net being open, nothing would prevent shallow pelagic animals from entering. This hypothesis is 
not very probable. We know, in fact, that the larvae of echinoderms known until now are encountered nearly exclusively in the vicinity of coasts and shallow-layers of these waters. They belong to well-known forms: Auricularia, Bipinnaria, Brachiolaria or Pluteus and are related to littoral species. Now, Stellosphara was collected by bathypelagic fishing in open seas, far from the coast, in a net descended to 2000 or $3000 \mathrm{~m}$ depth. We will agree that, in these conditions, it is reasonable to accept that this larva, which has characters absolutely new and recalling nothing of the known shallow-water larvae, come effectively from a great depth and belong to an abyssal asteroid. This is infinitely probable.

The discovery of Stellosphoera thus is of considerable interest. It throws a new light on the history of the development of abyssal echinoderms that is totally unknown to us. It shows us that some of them, at least, can develop as a larva.. 